\title{
EVOLUCIÓN HISTÓRICA DE LA LEGISLACIÓN DEL DELITO DE CONTRABANDO EN COLOMBIA*
}

\author{
Hernando A. Hernández Quintero** \\ Juan Manuel Barrero***
}

\begin{abstract}
Resumen: Tradicionalmente, los países han sancionado el contrabando por el perjuicio que puede ocasionar a su economía, pero también como una forma de arbitrarse recursos para su funcionamiento. Colombia ha castigado este comportamiento unas veces como infracción administrativa, otras como conducta punible y en no pocas ocasiones combinando las dos formas de reacción punitiva. En el presente artículo se realiza un estudio de la evolución legislativa para enfrentar este comportamiento en nuestro país, desde la colonia hasta la reciente Ley 1762 de 2015.
\end{abstract}

* El presente artículo es un producto de la investigación "Análisis del impacto económico y jurídico del contrabando de arroz en el Departamento del Tolima”, que adelantan los Grupos de Investigación Zoon Politikon y Unidere, de la Universidad de Ibagué. Fecha de recepción: 8 de septiembre de 2015. Fecha de modificación: $1 .^{\circ}$ de noviembre de 2015. Fecha de aceptación: 15 de enero de 2016. Para citar el artículo: HERnÁNDEZ Quintero, HERnANDO A. y BARRERO, JuAN MANuEl (2015). "Evolución histórica de la legislación del delito de contrabando en Colombia", Revista Derecho Penal y Criminología, Vol. 37 , n. ${ }^{\circ}$ 101, julio-diciembre de 2015. Bogotá: Universidad Externado de Colombia, pp. 13-49. DOI: http://dx.doi.org/10.18601/01210483.v36n101.02

** Doctor en Derecho de la Universidad Externado de Colombia. Magíster en Ciencias Penales y Criminológicas de la misma Universidad, de la cual es también especialista en Derecho Penal. Especialista en Legislación Financiera, de la Universidad de los Andes. Especialista en Derecho Penal, de la Universidad de Salamanca (España). Especialista en Ciencia Política, de la Universidad de Ibagué. Abogado de la Universidad Incca de Colombia. Profesor Titular de la Universidad de Ibagué y de Especialización en la Universidad Externado de Colombia. Docente de Maestría en la Universidad Libre de Colombia (Bogotá y Cali) y Simón Bolívar de Barranquilla. Ibagué, Colombia. Correo-e: hahernadezq@ hotmail.com.

*** Abogado de la Universidad de Ibagué. Docente en formación de la Universidad de Ibagué. Ibagué, Colombia. Correo-e: juan.baquero@unibague.edu.co. 
Palabras clave: Contrabando; Sanción administrativa; Conducta punible; Legislación; Despenalización.

\title{
HISTORIC EVOLUTION OF LEGISLATION PERTAINING THE FELONY OF CONTRABAND IN COLOMBIA
}

\begin{abstract}
States has traditionally sanctioned contraband, due not only to the detriment, it represents for their economies, but also as a manner on which those countries can collect resources for its operation throughout the imposition of fines and the seizing of merchandise. In the case study of the Colombian State, such behavior has been historically approached individually either as an administrative infringement, or as a criminal conduct; and even by combining the two as a punitive reaction. This paper presents a study of legislative evolution, legal approach used by the State of Colombia to face out such conduct, since the colonial times to the lately promulgated law 1765 of 2015. Keywords: Contraband; Administrative sanction; Punishable conduct; Legislation; decriminalization.
\end{abstract}

\section{A. PRESENTACIÓN}

El Derecho en la actualidad dista mucho de ser lo que fue durante el siglo xx, es decir, una disciplina aislada de las otras áreas del conocimiento; por ello, para el estudio de los comportamientos que lesionan o ponen en peligro los bienes jurídicos, no basta centrarse en la normatividad vigente, sino que es necesario un análisis histórico de las circunstancias que los motivaron y las normas que las regularon en el pasado, para contar con una visión más profunda y contextualizada que permita corregir las falencias actuales y evitar errores en su tipificación.

Con respecto al contrabando, encontramos que es una conducta vinculada históricamente con la estructura de la sociedad colombiana y que ha sido considerado desde la colonia como una grave infracción a las normas que regulan el comercio, con efectos nocivos en todas las actividades económicas y el desarrollo de los países. Así, introducir o sacar de un territorio mercancías sin el cumplimiento de las disposiciones legales, tales como el pago de impuestos, aranceles o el diligenciamiento de las formas pertinentes, priva a la nación de arbitrarse los recursos para su cabal funcionamiento, amén de estimular la competencia desleal, contribuir a la pérdida de empleos formales y generar un impacto en la moralidad pública.

Los gobiernos, a través de la historia, han sancionado el contrabando unas veces como contravención administrativa, ora como delito y, en no pocas ocasiones, combinando estas dos formas de castigo. En Colombia, las primeras normas datan de los decretos dictados por el general Simón Bolívar en los albores de nuestra nación, tales como los del 18 de julio de 1818 y 18 de marzo de 1824 , en los que se precisaba que las 
mercancías que se decomisaban como de contrabando eran adjudicadas al declarante. Ya en el Código común para todos los delitos, contenido en la Ley de 11 de marzo de 1848, se incorporó este comportamiento como conducta punible. Más tarde, la Ley 105 de 1873 recogió toda la legislación dispersa en un estatuto especial aduanero, la cual se subrogó luego por el Código Fiscal de la Ley 110 de 1912. Como resultado de la segunda Misión Kemmerer (1930), se propuso al Congreso un proyecto de código aduanero que seguía los parámetros del existente en los Estados Unidos, el cual se convirtió en la Ley 79 de 1931. Después de incontables reformas, se expidió el Decreto 955 de 18 de junio de 1970, que contiene el Estatuto Penal Aduanero que, con algunas modificaciones, estuvo vigente hasta que el país adoptó la política de apertura económica en el gobierno del presidente GAVIRIA en 1991. En efecto, con el Decreto 1750 de ese año, se extinguió la Justicia Penal Aduanera.

Con todo, como lo anotan IBÁÑEZ, OsPINA y NEVITo (2004, p. 122), la flexibilización de las normas y controles, propia de la internacionalización y la apertura económica, no produjo los efectos esperados sobre el desestímulo del contrabando, situación que obligó al país a penalizar nuevamente este comportamiento mediante la expedición de la Ley 383 del 10 de julio de 1997: “...por la cual se expiden normas tendientes a fortalecer la lucha contra la evasión y el contrabando, y se dictan otras disposiciones". Estas normas fueron luego incorporadas en el Código Penal dictado mediante la Ley 599 del año 2000, en el Capítulo IV del Título x de ese Estatuto, como un delito contra el Orden Económico Social.

En los últimos años se ha considerado que el contrabando constituye una de las formas más efectivas para dar apariencia de legalidad a los dineros provenientes de actividades ilícitas, razón por la cual en la Ley 190 de 1995 se le consideró como un comportamiento que agrava el punible de lavado de activos y en la Ley 1762 de 2015 se le ubica como un delito fuente de dicha conducta desviada. Para una mayor comprensión del delito de contrabando, a continuación efectuamos un recorrido histórico de su evolución legislativa en nuestro país.

\section{B. ETAPA DE 1823 A 1872}

Es extensa la regulación normativa que durante este periodo tuvo como objeto el delito de contrabando; así, encontramos normas de distinta naturaleza, expedidas con muy poca diferencia temporal, entre las que se destacan la Ley de agosto 5 de 1823, que establece las penas que deben aplicarse a los defraudadores de derechos en las aduanas litorales; el Decreto del 23 de noviembre de 1826, que impone penas a los defraudadores de la Hacienda pública; la Circular del 14 de julio de 1828, que modifica el decreto de 23 de noviembre de 1826 sobre penas a los contrabandistas; la Circular del 19 de julio de 1828, que adiciona penas a los contrabandistas; la Circular del 28 de agosto de 1828, que hace extensivos a todos los contrabandistas los efectos de las órdenes de 14 y 19 de julio; el Código Penal de 1837; la Ley del 11 
mayo de 1948, sobre código de procedimiento en los negocios criminales; la Ley del 14 de junio de 1847, orgánica de comercio de importación; la Ley del 27 mayo de 1853, adicional a la orgánica de comercio de importación; la Ley 74 de 1866, sobre aduanas, y la Ley 70 de 1872, adicional y reformatoria de las de Aduanas.

LAURENT (2008) afirma que en la legislación vigente, después de la independencia, se establecieron dos tipos de sanciones para el delito de contrabando: una que se podía aplicar a las mercancías y en algunas ocasiones al vehículo de transporte y otras a los sujetos activos de la conducta. De acuerdo con la misma autora, desde 1823 y hasta 1872 se fijaron sanciones sobre las mercancías como el decomiso del contrabando y del resto del cargamento y, en algunos casos, del medio de transporte de los objetos, entre ellos buques, carruajes y caballerías. Por otra parte, frente a las sanciones aplicables a los sujetos se consagraron sanciones de tipo social, como publicar en el periódico el nombre del ciudadano dueño del cargamento; políticos como la suspensión de sus derechos como ciudadano; privativas de la libertad como el presidio; y, más adelante, la suspensión del derecho de ejercer el comercio y de hacer operaciones bancarias o cambiarias (LAURENT, 2009, pp. 110, 112).

En cuanto al mismo periodo, en lo relacionado con los servidores públicos que colaboraran con el contrabando, la autora mencionada manifiesta que las sanciones que se les aplicaban eran más drásticas que las de los particulares. Es así como se encuentra que en 1822 se ratificó un decreto de 1819 en el que se castigaba a los empleados de la Hacienda nacional que hicieran fraude o malversación en los intereses públicos con pena de muerte y, si se trataba de "poco celo en el desempeño de su destino en perjuicio del erario nacional”, se destituía de su empleo y se podía destinar al servicio de las armas o a presidio, de acuerdo con las circunstancias. De esta forma, durante la época analizada, las penas a los servidores públicos variaron entre destitución del empleo, inhabilitación, presidio, pérdida de todos sus bienes si no tuviera hijos y de una tercera parte de sus bienes si tuviera hijos, perpetua, infamia y suspensión del cargo, que era la más común después de la primera mitad del siglo Xx (ídem, p. 114).

\section{ETAPA DE 1873 A 1962}

La Ley 105 de 1873 recopiló la dispersa legislación aduanera existente. En la normatividad se consagran por primera vez en Colombia las infracciones aduaneras, y son establecidas las sanciones y procedimientos, al igual que la competencia en los casos de contrabando. Al poco tiempo de sancionado ya se le habían realizado 162 reformas, lo que condujo a la expedición de un nuevo Código en 1905, el cual fue de efímera existencia debido a su poca claridad (CADAVID OROZCO, s.f., p. 29).

Por medio de la Ley 110 de 1912, se dictó el Código Fiscal que subrogó el Estatuto de Aduanas de 1873. Se afirma que es el primer Código que en el siglo Xx hace re- 
ferencia directa al contrabando como una forma de elusión de impuestos. En efecto, en su artículo 175 precisa:

Contrabando es el hecho de introducir al país productos de procedencia extranjera o el de tratar de ejecutarlo con el ánimo de no pagar el impuesto de aduana, o de pagar uno menor, o de violar una prohibición constitutiva o legal, agregando que también constituye este ilícito el hecho de tratar de exportar productos gravados con impuestos por razón de una operación comercial o con el ánimo de violar una prohibición de las clases indicadas (ídem, p. 30).

La Ley 96 de 1914 puede decirse que es el primer intento de independencia de la justicia aduanera del régimen fiscal. Esta disposición creó los Juzgados Distritales de Aduana con jurisdicción en los puertos marítimos de Barranquilla y Buenaventura, a los cuales correspondía la instrucción de los procesos por infracciones aduaneras, en tanto que la segunda instancia era competencia de los Tribunales Superiores de Distrito Judicial.

Para superar las deficiencias de la legislación aduanera, el gobierno contrató la Misión Kemmerer, la misma que en 1923 había recomendado la creación del Banco de la República, la Superintendencia Bancaria y la Contraloría General de la República. Los expertos presentaron entonces un proyecto de ley que, sin ninguna discusión en el Congreso, se convirtió en la Ley 79 de 1931, Orgánica de Aduanas. Esta nueva normatividad creó el Tribunal Superior de Aduanas que durante muchos años desempeñó sus funciones en la capital de la República, al igual que Tribunales Distritales de Aduanas en algunas ciudades del país; asimismo, estableció como sanción para el contrabando el decomiso de la mercancía y una multa proporcional, que se podía convertir en arresto en caso de no cancelarse dentro de los tres días siguientes a la notificación.

El Decreto 1432 de junio de 1940 eliminó los Tribunales Distritales y creó juzgados de Aduanas en las ciudades por donde regularmente se exportaba o importaba mercancías, esto es, Barranquilla, Buenaventura, Cartagena y Cúcuta, y prescribió para el delito de contrabando pena de arresto de un mes a dos años y la pena accesoria de la publicación de la sentencia, aplicando al reincidente la pena de relegación a colonia agrícola de tres meses a tres años.

Con el Decreto 3134 del 20 de diciembre de 1952, se estableció por primera vez la participación del $25 \%$ a denunciantes y aprehensores de productos de contrabando y se amenazó con pena de seis meses a dos años de prisión, estableciendo, también, la presunción de coautoría en el delito para el dueño de la nave, vehículo o aeronave, en que se transportara la mercancía ilegal cuando esta no fuera de servicio público.

Por un corto período estuvo vigente el Decreto 700 del 5 de marzo de 1954, que establecía las funciones para los Juzgados de Aduanas y los capitanes de barco, al 
Tribunal Superior de Aduanas y a los jueces de esa jurisdicción. Empero, por sentencia del 26 de julio de 1962, la Corte Suprema de Justicia declaró la inexequibilidad de la medida, a partir del 23 de septiembre de 1958.

Por medio del Decreto 0188 de 1958, se fijaron los procedimientos, penas y causales de casación en materia del delito de contrabando y se precisó que la Jurisdicción Aduanera la ejercían la Corte Suprema de Justicia, el Tribunal Superior de Aduanas, los Jueces Superiores y los Jueces de Instrucción Penal Aduanera. Por el delito de contrabando se establecieron penas entre tres y ocho años. Más tarde, con el Decreto 073 de 1958 independizó el régimen de aduanas.

\section{ETAPA DE 1963 A 1987 (VIGENCIA DEL ESTATUTO PENAL ADUANERO)}

La Ley 2 de 1963 otorgó facultades extraordinarias al Ejecutivo para tramitar una gran reforma judicial. En desarrollo de la misma, fue dictado el Decreto 1821 de 1964, conocido como de Reforma Penal Aduanera; en ella, se estableció una serie de presunciones de contrabando y se redujo la pena mínima por este ilícito a dos años (antes tres), aunque se mantuvo el máximo de ocho años.

El 17 de septiembre de 1969, al amparo del Estado de sitio, fue expedido un curioso Decreto Legislativo en el que se señala que no habrá detención preventiva en los procesos penales que por el delito de contrabando adelanten las autoridades con motivo de la aprehensión, en diversos lugares de expendio al público entre el 6 y el 30 de septiembre del presente año de mercancías ilegalmente introducidas al país. Asimismo, se precisa en el Decreto que, en estos eventos, se otorgará el perdón judicial, sin sujeción a los requisitos del artículo 80 del Código Penal. La norma especial la justificó el Ejecutivo en dos consideraciones especiales que transcribimos a continuación:

Que de años atrás ha existido en el país una atmósfera de tolerancia en relación con el ilícito de contrabando la cual pudo extraviar el criterio de algunas personas sobre las implicaciones y alcances de una conducta abiertamente reñida con los preceptos legales, circunstancia que mueve a considerar situaciones concretas.

Que conviene dar la oportunidad de rehabilitarse a quienes por causa del ambiente general encontraron en el expendio de mercancías ilegalmente importadas la fuente de su subsistencia ${ }^{1}$.

1 Diario Oficial n. 32.615 del 5 de octubre de 1969, p. 1. 
Ya en 1970, con el Decreto Ley 955 de junio 13, fue creado el Estatuto Penal Aduanero, modificado por el Decreto 520 de marzo 27 de 1971. En el en el Capítulo I, del Título II del Estatuto original se consagran como delitos el contrabando de mercancías de prohibida importación o exportación; el contrabando por fuera de las aduanas; el contrabando por las aduanas; la posesión de automotores, luego de expirada la autorización y la matrícula de automotores no autorizados.

Posteriormente, con la Ley 21 de 1977, se introducen algunas reformas al Estatuto Penal Aduanero, como el aumento del máximo de la punibilidad por el delito de contrabando, la cual puede llegar a diez años de prisión, y se prescinde del mínimo. Se modifica sustancialmente el sistema de tipificación de estos comportamientos, pues se establece el contrabando de primero y segundo grado, cada uno de ellos con la posibilidad de la comisión culposa. También se reducen las contravenciones penales aduaneras. Se advierte, asimismo, la posibilidad del concurso de delitos, y se descarta la figura del delito complejo. Se regula en la ley la competencia de los jueces superiores de aduanas y de los jueces de distrito penal aduanero. Finalmente, se precisa que los denunciantes del ilícito de contrabando y los aprehensores tendrán derecho a participar del producto líquido del remate o de la venta directa de la mercancía y efectos decomisados, en cuantía de sendos veinte por ciento $(20 \%)$.

Sobre esta nueva regulación típica del contrabando, comenta con acierto el recordado maestro Luis ENRIQue Aldana Rozo (1977, p. 106):

En la legislación recientemente promulgada se acogen criterios diferentes para la estructuración de los ilícitos, habida consideración de su gravedad; los más graves se fundamentan en el hecho de la ilícita importación o exportación y los más leves principalmente en la realización de conductas posteriores a la indebida introducción al país y en la violación de autorizaciones. Para los primeros se adopta el calificativo de contrabando de primer grado y para los demás contrabando de segundo grado, denominaciones que no aparecían consignadas en ninguno de los estatutos anteriores.

En cuanto a la consagración de la modalidad culposa del contrabando de primer y segundo grado, advierte el ilustre jurista que tiene por finalidad “...evitar que se queden impunes comportamientos en los cuales no aparezca claro el proceder doloso del agente y de otra parte esté demostrado que procedió en forma imprudente, imperita, negligente o con violación de normas o disposiciones legales o reglamentarias" (ídem, p. 109).

La Ley 9 de junio 15 de 1983, "Por la cual se expiden normas fiscales relacionadas con los impuestos de renta complementarios, aduanas, ventas, timbres nacional, se fijan unas tarifas y se dictan otras disposiciones", en el título VI, "Impuestos sobre aduanas", en el Capítulo I, “importadores y adquirentes de buena fe”, llenó enor- 
mes vacíos sustanciales y procedimentales que se presentaban con las personas que obraban en dicha condición (MONTEALEGRE LYNETT, 1985, p. 30).

Sobre los alcances y la importancia de estas normas expresó en su momento el doctor EduARDo MonteALEGRE LynETt, actual Fiscal General de la Nación:

La ley 9 de 1983, modificó la filosofía Draconiana del estatuto penal aduanero. Con base en esta ley puede afirmarse que si el importador o adquirente de buena fe obtiene a su favor una cesación de procedimiento, un sobreseimiento definitivo, un archivo temporal o una sentencia absolutoria, tiene derecho a obtener los beneficios de estas disposiciones, porque el supuesto de hecho de la norma sólo exige que la persona no hubiere participado en la comisión del ilícito. La no participación en el ilícito se puede demostrar a través de todo el proceso aduanero -cuando la persona ha sido vinculada-, o del trámite incidental cuando no está vinculada al proceso ni surgen pruebas para tomar tal medida. En conclusión, siempre que se demuestre la no participación en la comisión del hecho punible, el importador o el adquirente de buena fe, tienen derecho a que se les entregue la mercancía declarada de contrabando. En esto consiste la buena fe creadora de derechos (ídem, p. 35).

El Congreso de la República, por medio de la Ley 52 de 1984[2], otorgó al Presidente de la República facultades extraordinarias por el término de dos años para la expedición un nuevo Estatuto Penal Aduanero, sobre las mismas bases filosóficas y conceptuales que se señalan en esta para el Código de Procedimiento Penal ${ }^{3}$. Se destaca que una de las ideas de la ley es la creación de un sistema de actuación procesal que elimine en lo posible la escritura.

En desarrollo de las facultades extraordinarias mencionadas en el párrafo anterior, por medio del Decreto 051 de enero 13 de $1987^{[4]}$ se expidió una gran reforma aduanera considerada por los entendidos en el tema como integral y que contó con la participación de delegados del gobierno, comerciantes, transportadores, importadores y exportadores. Se destacan en esta nueva normatividad medidas para aligerar los depósitos de mercancías aprehendidas.

En el capítulo II del Estatuto se consagran las contravenciones penales aduaneras. En cuanto a la participación para particulares en razón a ser denunciantes o aprehensores de la mercancía de contrabando, el Estatuto establece que tendrán derecho

2 Diario Oficial n. 36.838 , del 14 de enero de 1985.

3 El artículo 2 de la Ley 52 de 1984, que autoriza elaborar y poner en vigencia un nuevo Estatuto Penal Aduanero, fue declarado exequible por la Corte Suprema de Justicia, en sentencia n. ${ }^{\circ} 72$ del 19 de septiembre de 1985, M.P. MANUEL GAONA CRUZ.

4 Diario Oficial n. ${ }^{\circ} 37.755$, del 13 de enero de 1987. 
a percibir el diez por ciento $(10 \%)$ del producto líquido del remate o venta directa de los bienes decomisados.

De otra parte, el nuevo Estatuto Aduanero deroga los Decretos-Ley 955 de 1970 y 520 de 1971, así como la Ley 21 de 1977, en los cuales se encontraba contenido el anterior Estatuto Aduanero.

\section{E. ETAPA DE 1987 A 1990 (INICIO DEL DESMONTE DEL DELITO DE CONTRABANDO)}

Apenas dos años después de expedido este nuevo Estatuto Aduanero, con respaldo en las facultades extraordinarias que el Congreso concedió al presidente por medio de la Ley 30 de $1987^{[5]}$, para “... asignar a otras autoridades o entidades trámites administrativos y otros no contenciosos, que actualmente están a cargo de los jueces", es dictado el Decreto 2274 de $1989^{[6]}$, "por el cual se modifica el Estatuto Penal Aduanero". La modificación fundamental se establece en el artículo 1. del Decreto en mención y guarda relación con la facultad que se concede a la Dirección General de Aduanas para ordenar el decomiso de las mercancías importadas al territorio nacional que no cumplan los requisitos establecidos para dicha operación y, para, si así lo declara, compulsar copias a la jurisdicción penal aduanera.

La norma es del siguiente tenor:

Artículo 1.- Toda mercancía que sea introducida al territorio nacional deberá ser presentada o declarada ante las autoridades aduaneras. La mercancía importada que sea sorprendida en lugares no habilitados por la Aduana para el ingreso y permanencia de la mercancía que se introduzca al país, será decomisada si con relación a ella no se acredita el cumplimiento previo de los trámites correspondientes a su presentación, declaración o despacho, en los términos previstos en el régimen aduanero. Tal mercancía será de propiedad de la Nación, en virtud del acto de decomiso que así lo disponga. La expedición de dicho acto será de competencia de la Dirección General de Aduanas y copia del mismo se remitirá de inmediato a la jurisdicción penal aduanera para iniciar lo de su competencia.

Parágrafo 1. ${ }^{\circ}$ Lo previsto en el presente Artículo se aplicará en lo pertinente a los casos de depósito y transporte no autorizado de café.

5 Diario Oficial n. ${ }^{\circ} 38.077$, del 9 de octubre de 1987.

6 Diario Oficial del 7 de octubre de 1989. 
Parágrafo 2. ${ }^{\circ}$ Se procederá conforme a lo dispuesto en este Artículo sin perjuicio de la acción penal a que hubiere lugar para efectos de la determinación de la responsabilidad y sanciones pertinentes. En cualquier caso, toda determinación referente al carácter y valor de la mercancía será de responsabilidad de la Dirección General de Aduanas.

Esta norma recibió en su momento la crítica de autorizados doctrinantes que consideraron que con ella se establecía una supremacía de la rama administrativa sobre la judicial, la cual debía esperar los resultados de las averiguaciones adelantas por la Dirección General de Aduanas y de las copias que esta entidad le diera traslado proceder a la correspondiente investigación penal (MEDINA LóPEZ, 1991, p. 22).

Mediante sentencia n. 83 del 26 de junio de 1990, la Corte Suprema de Justicia declaró exequible el Decreto 2274 de 1989. Los fundamentos de la decisión de la alta corporación se pueden resumir en los siguientes apartes:

Así, pues, mal podría aducirse una pretendida trasgresión al principio de separación de los poderes cuando la órbita de actuación de la Dirección General de Aduanas y la de la jurisdicción penal aduanera está claramente diferenciada y estas ejercen sus funciones dentro de la esfera de competencia y de acción que a cada una le es propia. Nótese que la Dirección General de Aduanas no califica el delito de contrabando ni el comportamiento del contrabandista pues su función, conforme a los artículos $1 .^{\circ}$ y $2 .^{\circ}$ del Decreto 2274 , se limita a establecer si una determinada mercancía ingresó o permanece legalmente en el territorio nacional y a decomisarla cuando se ha importado con violación a los requisitos previstos en el régimen aduanero. Por tanto, la Dirección General de Aduanas no califica el delito de contrabando sino la falta administrativa configurada por la contravención al régimen de aduanas...

Más adelante justifica la legalidad del Decreto acudiendo a las expresiones contenidas en los artículos primero y el segundo. Señala la Corte:

De otra parte, frente a los preceptos últimamente citados, vale la pena observar que dichas disposiciones de manera alguna están impidiendo que el juez penal aduanero oficiosamente o por denuncia aprehenda el conocimiento e inicie la investigación penal correspondiente, por cual por este aspecto el cargo que aduce una supuesta subordinación de la función jurisdiccional a la rama administrativa para sustentar violación a los artículos 55 y 58 constitucionales, tampoco prospera.

Frente a la decisión de la mayoría de la Corte Suprema de Justicia salvaron el voto los magistrados Jorge Carreño Luengas, Rafael Baquero Herrera, Guillermo Duque Ruiz, Rafael Romero Sierra, Ricardo Calvete Rangel, Jacobo Pérez 
Escobar, Édgar SaAVedra Rojas y Jorge EnRique Valencia Martínez. Se advierte que la mayoría pertenecía a la Sala Penal de la Corporación.

Dos son los fundamentos centrales de la disidencia de los ilustres juristas. El primero, considerar que se interpretó en forma equivocada el término "simplificar", a que se refiere la ley de Facultades Extraordinarias. La segunda, siguiendo el criterio que tradicionalmente había adoptado la corporación en relación con el decomiso, es una sanción que surge del delito y no de la decisión de una autoridad administrativa.

Transcribimos a continuación algunos de los apartes más importantes del salvamento de voto en mención:

El traspasar a las autoridades de la Dirección General de Aduanas la facultad de decomisar la mercancía o destruirla en ciertos eventos, o cercenar la capacidad investigativa de los jueces penales de aduanas no pueden incluirse dentro de la potestad de simplificar, porque esta debe entenderse como la búsqueda de nuevas instituciones o transformaciones de otras que abrevien el proceso, que lo hagan menos denso y más célebre; pero la facultad de simplificación, necesariamente ha de entenderse -y esto es obvio por razones mínimas de constitucionalidad-, dentro del mismo proceso judicial, porque así expresamente lo estipula la norma de facultades. Por eso cuando un trámite judicial, eminentemente contencioso como es el decomiso de propiedad privada, se traslada en su competencia a las autoridades administrativas, no se está simplificando, sino que se está cercenado una facultad jurisdiccional de carácter constitucional (artículos 30 y 33 de la Constitución Nacional).

En cuanto a la segunda razón de fondo para apartarse de la mayoría, precisaron los magistrados que suscriben el salvamento de voto:

... Debe recordarse en este punto que la reiterada doctrina de la Sala Plena de la Corte gira sobre la base de que el decomiso es una sanción que surge propiamente del delito y que no constituye confiscación, ni se afectan las disposiciones constitucionales referidas a la propiedad privada; pero cuando el decomiso como consecuencia, es separado de la actividad ilícita como en el evento a que se refiere la decisión de la mayoría, puesto que éste se crea como un prerrequisito de procedibilidad penal, es apenas lógico concluir que se trata o de una confiscación de prohibida existencia constitucional o será en caso similar una expropiación, y a este respecto debe recordarse el contenido del artículo 33, que limita este fenómeno jurídico sólo a estados de guerra y únicamente para atender el restablecimiento del orden público, ocasión en la cual "la necesidad de una expropiación podrá ser decretada por autoridades que no pertenezcan al orden judicial"; pero óigase bien, sólo en caso de guerra y con el condicionamiento a que antes se hizo referencia. 
Es ésta la única oportunidad en que la expropiación puede ser decretada por funcionarios administrativos.

Debe, sí, advertirse que la disposición que se comenta solo aplica para los eventos de importaciones, con lo cual se precisa que no cobija los delitos de contrabando de exportación, contrabando por matrícula irregular de automotores importados temporalmente, contrabando interno de café; contrabando de mercancías de circulación restringida y a las contravenciones penales aduaneras. En estos eventos, sin ningún requisito previo, conserva plena competencia la justicia aduanera (ídem, pp. 28-29).

Con posterioridad al Decreto 2274 de 1989, fueron dictadas otras disposiciones relacionadas con aspectos administrativos del contrabando, tales como la aprehensión y el decomiso de mercancías (Decreto 2352 de 17 de diciembre de 1989); el Decreto 755 del 11 de abril de 1990, sobre el nacimiento de la obligación aduanera; el Decreto 392 del 12 de febrero de 1990, sobre enajenación y destino de mercancías aprehendidas, decomisadas y abandonadas a favor de la Nación, y la Ley 18 de 1990, que prohibió la fabricación, importación, distribución, venta y uso de juguetes bélicos en el territorio nacional.

\section{F. ETAPA DE 1990 A 1997 (DESPENALIZACIÓN DEL CONTRABANDO)}

El Congreso de la República, por medio de la Ley 49 de diciembre 28 de 1990 [7] "Por la cual se reglamenta la repatriación de capitales, se estimula el mercado accionario, se dictan normas en materia tributaria, aduanera y se dictan otras disposiciones", otorgó facultades extraordinarias al presidente de la República para "Eliminar el carácter de hecho punible tipificado en el Estatuto Penal Aduanero de las conductas que infrinjan la legislación aduanera y suprimir la Jurisdicción Penal Aduanera. En ejercicio de esta facultad podrá: a) Efectuar las modificaciones pertinentes en la legislación penal sustantiva y procesal vigente".

Al rastrear los motivos por los cuales el gobierno nacional consideraba que se debía despenalizar el contrabando, se encuentran en la exposición de motivos de la Ley 49 de 1990, los siguientes argumentos de los ministros de Hacienda y Crédito Público, de Justicia, de Trabajo y de Seguridad Social:

En el marco de la modernización se ha revisado y reglamentado la legislación aduanera vigente, buscando siempre consultar los avances de la técnica internacional, la simplificación y agilización de la gestión. Los más importantes cambios se han producido mediante los decretos 755 y 1622 de 1990 respecto

7 Diario Oficial n. ${ }^{\circ} 39615$, del 31 de diciembre de 1990. 
de las importaciones y el 1144 de 1990 que establece un nuevo sistema de exportaciones.

Reconociendo que lo anterior constituye un avance importante en la modernización y desarrollo del Servicio Aduanero, la actual situación económica y la apertura al comercio internacional obligan al gobierno a plantearse un desafío que exige nuevas transformaciones en el mismo, para lo cual se solicitan facultades extraordinarias para:

Desjudicializar las conductas contrabandéales, eliminando su carácter de hecho punible y por ende la Jurisdicción Penal Aduanera. Para lo cual se establecerán mecanismos para reubicar a los actuales funcionarios de dicha jurisdicción en la planta de personal de la Rama.

Con el fin de llevar a cabo esta reforma se hace necesario consolidar $y$ cualificar un tratamiento uniforme para conocer y sancionar las conductas que afectan a la economía o el orden económico, con sanciones de carácter económico impuestas por la autoridad administrativa. Así, por ejemplo, la Dirección de Impuestos castiga a los infractores con sanciones pecuniarias, suspensiones y cierres de establecimientos comerciales; la Superintendencia de Control de Cambios sanciona directamente a quien viola el control de cambios con medidas pecuniarias ${ }^{8}$.

A nuestro juicio, el argumento que se presenta en el último párrafo trascrito no se ajusta a la realidad jurídica del país, pues debe mencionarse que desde la expedición del Código Penal de 1980 (Decreto 100), muchos comportamientos antes sancionados por vía administrativa se llevaron al Estatuto como hechos punibles. Por mencionar solo algunos, citamos el delito de exportación ficticia (art. 240) y la aplicación fraudulenta de crédito oficialmente regulado (art. 241). Lo mismo sucedió con la utilización indebida de los recursos captados del público; la concentración de créditos y la captación masiva y habitual de dineros, que, además de la sanción administrativa por parte de la Superintendencia Bancaria (hoy Superintendencia Financiera), se erigieron en delitos por mandato del Decreto 2920 de 1982, hoy incorporado al Código Penal en vigencia (Ley 599 de 2.000).

En el trámite del proyecto de ley de autorizaciones en la ponencia para primer debate en el Senado de la República, Víctor RENÁn BARCO argumentó a favor de la eliminación del delito de contrabando la tendencia internacional contemporánea de sancionar pecuniariamente este comportamiento y no por la vía penal. En soporte de su tesis, cita las legislaciones de Chile e Italia. Explica, además, que la multa se configura entonces “....como un elemento de resarcimiento al desequilibrio causado

8 Tomado de la Sentencia n. ${ }^{\circ}$ C-549 del 5 de octubre de 1992. M.P. Simón RodRíGuEz RodRíGUEz. 
al orden económico, con ocasión de las infracciones aduaneras. La sanción tendría entonces un carácter económico, acorde con el tratamiento punitivo propio del régimen tributario o cambiario".

En la ponencia para primer debate en la Cámara de Representantes, congresista Rodrigo Garavito Hernández sustentó la conveniencia del proyecto por la poca efectividad de la Justicia Penal Aduanera. Afirmó entonces el legislador:

En efecto, un estudio presentado en el Congreso Nacional de Fenalco (1988) señalaba que según datos del Tribunal Superior de Aduanas, en julio de 1987 había 28.000 procesos en estudio y sólo 28 casos culminaron en condena para los procesados, es decir, el $0.1 \%$.

Pues bien, en desarrollo de las facultades otorgadas al presidente de la República, el gobierno expidió el Decreto 1750 de 4 de julio de 1991 [9], "Por el cual se ejercen facultades extraordinarias en materia penal Aduanera". Para cumplir cabalmente la autorización de eliminar los hechos punibles sancionados hasta ese momento por el Estatuto Penal Aduanero, el gobierno consideró que la vía adecuada era transmutar dichos hechos punibles en infracciones de carácter administrativo. Así lo precisó en el artículo $1 .^{\circ}$ de la norma, al señalar:

Artículo 1. . A partir del 1. ${ }^{\circ}$ de noviembre de 1991 eliminase el carácter de hecho punible de las conductas tipificadas en el Estatuto Penal Aduanero. A partir de tal fecha dicho carácter se transmutará en el de las siguientes infracciones administrativas aduaneras.

a) Contrabando: incurrirá en infracción administrativa de contrabando quien realice una cualquiera de las siguientes conductas:

1. Importar o exportar mercancías de prohibida importación o exportación.

2. Importar o exportar o intentar exportar mercancías sin presentarlas o declararlas ante la autoridad aduanera, o por lugares no habilitados.

3. Sustraer del control de Aduana mercancía que no haya sido despachada para consumo o respecto de la cual no se haya autorizado Régimen Aduanero alguno.

4. Transportar, almacenar, tener, poseer, adquirir, vender, permutar, ocultar, usar, dar o recibir en depósito, destruir o transformar mercancía introducida al país de contrabando, sin participar en los hechos descritos anteriormente.

9 Diario Oficial n. 39.889 , del 4 de julio de 1991. 
Ser propietario, administrador o tenedor de trilladoras o tostadoras de café que funcionen sin autorización de la Dirección General de Aduana.

5. Tener, poseer o almacenar café en lugares no autorizados, o transportarlo por rutas distintas de las autorizadas, o en medio de transporte no inscrito en la Dirección General de Aduanas, sin la guía de tránsito o el certificado de revisión.

6. Intervenir, sin permiso de autoridad competente, en el traspaso o matrícula irregular de automotor importado temporalmente o de contrabando.

7. Sin permiso de autoridad competente, poner en libre circulación, mercancías de circulación restringida tales como las importadas temporalmente para reexportación en el mismo estado o para perfeccionamiento activo.

En el artículo 2. ${ }^{\circ}$ del decreto, se señala como sanción aplicable a los responsables de las infracciones mencionadas en precedencia una multa y también se establecen algunas sanciones accesorias, como la prohibición de ejercer el comercio; la clausura y cierre de establecimiento comercial; la prohibición de ejercer profesión u oficio relacionado con el Comercio Exterior, y la pérdida de empleo o cargo público.

Esta drástica medida de convertir las conductas que antes eran delictuales a simples contravenciones administrativas (especiales) recibió en su momento fuertes críticas de algunos doctrinantes. Así, Roberto López MedinA, desde que se presentó ante el Congreso el Proyecto de facultades al gobierno para despenalizar el delito de contrabando, envió al Legislativo un extenso memorial en el que expresaba las razones para mantener la vigencia de los tipos penales consagrados en el Estatuto Penal Aduanero. Entre ellas resaltamos las siguientes:

Consideramos que las conductas contrabandeables son eminentemente dañosas puesto que transgreden el orden público económico. Toda Carta Fundamental diseña un modelo de intervención dentro del cual surgen intereses que el constituyente reconoce y ampara y que, por ello, se convierten en objeto de especial protección jurídica.

El contrabando, por lo menos en su manifestación primaria que es la violación de la línea aduanera, debe ser considerado un delito. No se trata de una mera defraudación fiscal; lesiona gravemente la economía nacional, las transacciones comerciales, el comercio internacional, el régimen cambiario, la política laboral, la industria nacional y genera otros delitos, particularmente el cohecho, la concusión y la falsedad documental. Esto hace del contrabando un delito económico, por que afecta el ámbito de la actividad interventora y reguladora del Estado en la economía, que protege bienes jurídicos colectivos, 
supraindividuales, vinculados al bien común, al orden económico estatal en su conjunto (MEDINA LóPEZ, Op. cit., p. 10).

La Corte Constitucional declaró exequible el artículo $1^{\circ}$ del Decreto 1750 de 1991 que, como se ha mencionado, transmutó los hechos punibles del Estatuto Penal Aduanero en infracciones especiales. Para arribar a su conclusión, la alta corporación realizó un importante estudio sobre las diferencias existentes entre los hechos punibles, las contravenciones penales y las infracciones administrativas, advirtiendo que "en el sentido del derecho penal las infracciones administrativas no son contravenciones, en consecuencia, no quedan comprendidas dentro de lo que se conoce como hecho punible". De esta forma, concluye que el Decreto 1750 de 1991 "transmutó el carácter de hecho punible de las conductas que infringe la legislación aduanera, en infracciones de naturaleza administrativa, no rebasó las facultades extraordinarias que al efecto le confirió el Congreso al Presidente de la República mediante la Ley 49 de 1990”.

Agrega la Corte Constitucional que obró bien el gobierno al transmutar los delitos en contravenciones administrativas pues, de no haber procedido así, "además de desconocer la voluntad de legislador, expresada en tal sentido el remedio habría sido peor porque el resultado del desarrollo por el Ejecutivo de la Ley 49 habría consistido en eliminar el delito de contrabando nada más y dejar sin ninguna otra sanción las conductas que lo tipificaban".

\section{G. ETAPA DE 1997 A 2015 (NUEVA PENALIZACIÓN DEL DELITO DE CONTRABANDO)}

Pocos años después de la despenalización del contrabando, el gobierno aceptó que la medida no había logrado los fines que se propuso, a pesar de la internacionalización de la economía que se había diseñado desde la llegada al poder del presidente CÉSAR Gaviria TrujiLlo, en 1990. Por el contrario, esta conducta desviada se multiplicó y empezó a notarse su conexión con el lavado de lavado de activos, al punto que la Ley 190 de 1995 (Estatuto Anticorrupción) que lo tipificó por primera vez en nuestra patria, incluyó como agravante de ese punible el que se introduzcan mercancías al territorio aduanero nacional.

Ante esta situación, el Congreso de la República dictó la Ley 383 del 10 de julio de 1997[10] "Por la cual se expiden normas tendientes a fortalecer la lucha contra la evasión y el contrabando y se dictan otras disposiciones". Esta norma creó los tipos penales de: contrabando; favorecimiento de contrabando; defraudación a las rentas de aduana, y el favorecimiento por servidor público.

10 Diario Oficial n. ${ }^{\circ} 43083$, del 14 de julio de 1997. 
En la exposición de motivos, se sostiene que el avance del contrabando y su relación con otros graves delitos, como el narcotráfico y el lavado de activos, recomiendan utilizar una herramienta más fuerte que el Derecho administrativo, esto es, el Derecho penal. Asimismo, se advierte que la evasión tributaria y el contrabando son delitos que lesionan en forma severa el orden económico social. Para mayor precisión, se trascribe algunas de las consideraciones del proyecto de ley:

La lucha contra el contrabando se ha convertido en uno de los más difíciles retos que ha enfrentado la actual administración. Dada la variedad de causas determinantes de dicha conducta tales como la cultura de la ilegalidad (...), el lavado de activos provenientes de actividades ilícitas, que han encontrado en el contrabando el mecanismo ilegal para introducir dineros producto del tráfico ilícito de drogas, y el hecho mismo de obtener lucro con el no pago de tributos, las medidas que se han venido adoptando definitivamente, se han quedado cortas por las limitadas posibilidades que la normatividad ofrece en la actualidad...

Y más adelante se agrega:

La evasión tributaria y el contrabando deben considerarse defraudaciones fiscales que lesionan gravemente la economía nacional, la competencia leal entre los diferentes agentes, las transacciones comerciales, el comercio internacional, el régimen cambiario, la política laboral y la industria nacional, vinculándose en varias oportunidades con otros delitos como el cohecho, la concusión y la falsedad documental.

Los bienes vulnerados son colectivos y supraindividuales, el orden público económico se transgrede con el incumplimiento del pago de los tributos internos y externos, razón por la cual merece una categorización más drástica que la simple contravención ${ }^{11}$.

Las normas penales de la ley son del siguiente contenido:

Artículo 15. Contrabando. Quien introduzca o saque bienes del territorio nacional, sin declararlos o presentarlos ante la autoridad aduanera, o por lugar no habilitado o sin los documentos soporte de la operación de comercio exterior, incurrirá en pena de prisión de tres (3) a seis (6) años, y multa equivalente al doscientos por ciento (200\%) del valor CIF de los bienes involucrados, sin perjuicio del concurso de hechos punibles.

11 Tomado de la sentencia de la Corte Constitucional C-194/98, del 7 de mayo de 1998, M.P. HERNANDO HERRERA VERGARA. 
La pena descrita en el inciso primero no se aplicará cuando la cuantía de los bienes involucrados sea inferior a mil (1000) salarios mínimos legales mensuales vigentes, sin perjuicio de las sanciones administrativas.

Parágrafo $1 .^{\circ}$ Los vehículos automotores que transiten en departamentos que tienen zonas de frontera de acuerdo con lo estipulado en el artículo 272 de la Ley 223 de diciembre de 1995, no estarán sometidos a los establecidos en este artículo.

Parágrafo $2 .^{\circ}$ Cuando el contrabando por cuantía superior a mil salarios mínimos legales mensuales vigentes se realice fraccionadamente en diferentes actos de inferior importe cada uno y sean sancionados administrativamente, se tendrán estos el carácter de delito continuado si existe unidad de propósito y así se infiere de la identidad de su autor y de los medios utilizados en su comisión.

Artículo 16. Favorecimiento de contrabando. El que en cuantía superior a cien (100) salarios mínimos legales mensuales vigentes transporte, almacene, distribuya o enajene mercancía introducida al territorio nacional sin haber sido declarada, o sin haber sido presentada ante la autoridad aduanera, o ingresada por lugar no habilitado, o sin los documentos de soporte, incurrirá en pena de arresto de seis (6) a veinticuatro (24) meses y multa de cien (100) a quinientos (500) salarios mínimos legales mensuales vigentes, sin perjuicio de las sanciones administrativas a que haya lugar.

El juez al imponer la pena, privará al responsable del derecho de ejercer el comercio por el término de arresto y un (1) año más.

Parágrafo transitorio. Para los efectos del presente artículo, no serán responsables penalmente los comerciantes minoristas que, dentro de los dos meses siguientes a la entrada en vigor de la presente ley, presenten ante la Administración de Impuestos y Aduanas Nacionales de su jurisdicción, relación de las mercancías respecto de las cuales no se pueda acreditar su legal introducción o permanencia en el territorio nacional, y que a más tardar dentro de los cuatro meses siguientes a la entrada en vigor de la presente ley, las legalicen de conformidad con lo establecido en los artículos 57, 58 y 82 del Decreto 1909 de 1992.

La eximente de responsabilidad establecida en este parágrafo, se aplica de manera exclusiva respecto de las mercancías legalizadas en el plazo aquí establecido.

Artículo 17. Defraudación a las rentas de aduana. El que declare tributos aduaneros por un valor inferior al que por ley le corresponde, en una cuantía 
superior a veinte (20) salarios mínimos legales mensuales vigentes, incurrirá en pena de multa equivalente a veinte (20) veces lo dejado de declarar por concepto de tributos aduaneros.

Parágrafo. Lo dispuesto en el presente artículo no se aplica en los casos en que el valor informado corresponda a controversias sobre clasificación arancelaria.

Artículo 16. Favorecimiento por servidor público. El servidor público que colabore, participe, transporte, distribuya, enajene o de cualquier forma facilite la introducción de mercancía de prohibida importación al país, o el ingreso de mercancía sin declarar o sin presentar ante la autoridad aduanera, o por lugar no habilitados o sin los documentos soporte, u omita los controles legales o reglamentarios propios de su cargo para lograr los mismos fines, incurrirá en prisión de dos (2) a cuatro (4) años y la pérdida e interdicción de las funciones públicas.

La pena se aumentará de una tercera parte a la mitad si el favorecimiento se presenta en ejercicio de sus funciones, sin perjuicio del concurso de hechos punibles.

La Corte Constitucional, en Sentencia C-194 del 7 de mayo de 1998, declaró exequibles los artículos relacionados en precedencia por considerar que no vulneraban el artículo 29 de la Constitución Política que consagra el debido proceso, pues resulta claro para la alta corporación la total independencia de sanción administrativa aduanera y la sanción por el hecho punible, imponibles por autoridades diferentes; la primera por la Dirección de Impuestos y Aduanas Nacionales y la segunda, por los jueces de la República, sin que se viole el principio del non bis in idem.

En palabras de la Corte Constitucional,

De ahí que, el proceso administrativo es independiente del juicio penal, de manera que el trámite y decisión de uno y otro corresponde a autoridades diferentes. Por consiguiente, frente a la configuración de los hechos punibles relacionados en las normas acusadas, el funcionario administrativo o la autoridad aduanera están en la obligación de ponerlo en conocimiento de la autoridad judicial (artículo 25 CPP.) para los efectos de imponer las sanciones penales a que haya lugar, mediante la sentencia respectiva.

Así pues, el ámbito de competencias de las mencionadas autoridades, es decir, de las administrativa de un lado y la judicial del otro, en relación con las faltas cometidas, para la aplicación de las respectivas sanciones, es totalmente diferente, sin perjuicio de que el funcionario administrativo pueda remitir las diligencias procesales al funcionario judicial competente, a fin de determinar la responsabilidad penal del comerciante inculpado, que en 
el evento de su exoneración, puede ejercer las acciones encaminadas a la reparación directa por los perjuicios que haya sufrido, consagradas en las normas vigentes.

Por lo anteriormente expresado, estima la Corte que no existe vulneración alguna al derecho fundamental al debido proceso, consagrado en el artículo 29 de la Carta Política, ni violación al principio según el cual se prohíbe juzgar a una misma persona dos veces por el mismo hecho, ya que con fundamento en los criterios expuestos, resulta evidente la diferencia entre la sanción administrativa producto del quebranto de las normas aduaneras y tributarias que exigen el cumplimiento de las formalidades y requisitos para el ingreso o egreso de mercancías y bienes al territorio nacional, encaminadas a la defensa de la economía nacional, y las consecuencias jurídico penales que se derivan de la conducta punible, que implican para quien incurre en el hecho delictivo la sanción penal que debe ser impuesta por la autoridad judicial competente, previa la observación del debido proceso y del derecho de defensa, tanto en las actuaciones administrativas como en las judiciales.

Con todo, algunos reconocidos tratadistas manifestaron su inconformidad con la penalización del contrabando. Así, DARío BASAN MONTOYA resalta como argumentos para mantener la sanción de este comportamiento por vía administrativa las siguientes:

a) Desproporción de las penas previstas, falta de necesidad.

b) Posibilidad de protección mediante el ejercicio de las sanciones administrativas con efectos más nocivos para el comerciante, quien no podría decirse, es un desadaptado social o cuya permanencia en la comunidad amenace la integridad y la vida de sus integrantes o del Estado mismo.

c) Inidoneidad de las penas para tutela eficaz.

d) Si bien hay lesión de un bien jurídico, debe tenerse en cuenta que ésta es condición necesaria mas no suficiente para la aplicación del derecho penal. Pues, como lo dijera FERRAJOLI ningún bien justifica una protección penal -en lugar de civil o administrativa- si su valor no es mayor que el de los bienes de que priva la pena.

e) Y volatilidad del bien jurídico orden económico, cuyo contenido y alcances siempre serán fluctuantes y determinados por el mismo poder que ejerce el ius puniendi (BASSANI MONTOYA, 2001, p. 72). 
Por medio de la Ley 488 de diciembre 24 de $1998^{[12]}$, se reformó nuevamente la regulación penal del contrabando.

En el mes de julio de 2000, fue expedido un nuevo Código Penal (Ley 599) ${ }^{13}$, en la que el delito de contrabando fue incorporado como Capítulo cuarto del Título $\mathrm{X}$ (Delitos contra el orden económico social). De esta manera, se sigue de cerca uno de los propósitos que orientaron a la Fiscalía General de la Nación al presentar un proyecto de ley para actualizar el Estatuto Penal, esto es, incluir en este código todas las figuras punibles que se encontraban dispersas en razón a ser expedidas a través de leyes o decretos por fuera del Código de Penas. De esta forma, se repite, con algunas modificaciones en cuanto a la multa, los tipos penales existentes en la Ley 488 de 1998.

Así, los tipos penales de contrabando son del siguiente tenor:

Artículo 319.- Contrabando. El que en cuantía entre cien (100) a doscientos (200) salarios mínimos legales mensuales vigentes importe mercancías al territorio colombiano, o las exporte desde él, por lugares no habilitados, o las oculte, disimule o sustraiga de la intervención y control aduanero incurrirá en prisión de tres (3) a cinco (5) años y multa de trescientos (300) a mil quinientos (1.500) salarios mínimos legales mensuales vigentes, sin que en ningún caso sea inferior al doscientos por ciento (200\%) del valor CIF de los bienes importados o del valor FOB de los bienes exportados.

Si la conducta descrita en el inciso anterior recae sobre mercancías cuyo valor supere los doscientos (200) salarios mínimos legales vigentes, se impondrá una pena de cinco (5) a ocho (8) años de prisión y multa de mil quinientos (1.500) a cincuenta mil (50.000) salarios mínimos legales mensuales vigentes, sin que en ningún caso sea inferior al doscientos por ciento $(200 \%)$ del valor CIF de los bienes importados o del valor FOB de los bienes exportados.

El monto de la multa no podrá superar el máximo de la pena de multa establecido en este código.

Las penas previstas en el presente artículo se aumentará en la mitad a las tres cuartas partes (3/4) cuando se demuestre que el sujeto activo de la conducta es reincidente.

12 Diario Oficial n..$^{\circ} 43.460$, del 28 de diciembre de 1998.

13 Diario Oficial n. ${ }^{\circ} 44.07$, del 24 de julio de 2000. 
Parágrafo 1.- Los vehículos automotores que transiten en departamentos que tienen zonas de fronteras, de acuerdo con lo estipulado en el artículo 272 de la Ley 223 de 1995, no estarán sometidos a lo establecido en este Artículo.

Parágrafo 2.- La legalización de las mercancías no extingue la acción penal.

Artículo 320.- Favorecimiento de contrabando. El que en cuantía superior a cien (100) salarios mínimos legales mensuales vigentes, posea, tenga, transporte, almacene, distribuya o enajene mercancía introducida al territorio colombiano por lugares no habilitados, u ocultada, disimulada o sustraída de la intervención y control aduanero, incurrirá en pena de prisión de uno (1) a cinco (5) años y multa de doscientos (200) a cincuenta mil (50.000) salarios mínimos legales mensuales vigentes, sin que en ningún caso sea inferior al doscientos por ciento (200\%) del valor CIF de los bienes importados. El monto de la multa no podrá superar el máximo de pena de multa establecido en este código.

El Juez al imponer la pena, privará al responsable del derecho de ejercer el comercio por el término de la pena y un (1) año más.

No se aplicará lo dispuesto en el presente artículo al consumidor final cuando los bienes que se encuentren en su poder, estén soportados con factura o documentos equivalentes, con el lleno de de los requisitos legales contemplados en el Artículo 771-2 del estatuto tributario.

Artículo 321.- Defraudación a las rentas de aduana. El que declare tributos aduaneros por un valor inferior al que por ley le corresponde, en una cuantía superior a veinte (20) salarios mínimos legales mensuales vigentes, incurrirá en pena de prisión de cinco (5) a ocho (8) años y multa equivalente a veinte (20) veces lo dejado de declarar por concepto de tributos aduaneros. El monto de la multa no podrá superar el máximo de la pena de multa establecida en este código.

Parágrafo.- Lo dispuesto en el presente artículo no se aplicará cuando el menor valor de los tributos aduaneros declarados corresponda a controversias sobre valoración, error aritmético en la liquidación de tributos o clasificación arancelaria, sin perjuicio de la aplicación de las sanciones administrativas establecidas en la ley.

Artículo 322.- Favorecimiento por servidor público. El servidor público que colabore, participe, transporte, distribuya, enajene o de cualquier forma facilite la sustracción, ocultamiento o disimulo de mercancías del control de las autoridades aduaneras, o la introducción de las mismas por lugares no habilitados, u omita los controles legales o reglamentarios propios de su cargo para lograr 
los mismos fines, cuando el valor de la mercancía involucrada sea inferior a cien (100) salarios mínimos legales mensuales vigentes, incurrirá en multa de trescientos (300) a mil quinientos (1.500) salarios mínimos legales mensuales vigentes, sin que en ningún caso sea inferior al doscientos por ciento (200\%) del valor CIF de los bienes involucrados e inhabilitados para el ejercicio de los derechos y funciones públicas de tres (3) a cinco años.

Si la conducta descrita en el inciso anterior recae sobre mercancías cuyo valor supere los cien (100) salarios mínimos legales mensuales vigentes, se impondrá una pena de prisión de cinco (5) a ocho (8) años, multa de mil quinientos (1.500) a cincuenta mil (50.000) salarios mínimos legales mensuales vigentes, sin que en ningún caso sea inferior al doscientos por ciento (200\%) del valor CIF de los bienes involucrados, e inhabilitación para el ejercicio de derechos y funciones públicas de cinco (5) a ocho (8) años.

El monto de la multa no podrá superar el máximo de la pena de multa establecida en este código.

\section{La tipificación del delito de contrabando de combustibles}

El hurto de combustibles impactó fuertemente las finanzas del país al finalizar la década del noventa, especialmente en cuanto a la baja sustancial del recaudo del IVA y la sobretasa a la gasolina que, según información del gobierno, alcanzó la suma de USD\$148 millones (Gaceta del Congreso 183 de 2005). Esta situación generó que el gobierno, en desarrollo de la Conmoción Interior ordenada con el Decreto 1837 de 2002, dictara el Decreto 1900 de 2002, en el que se crearon varios tipos penales relacionados con el hurto de combustibles. De esta forma, nacieron los delitos de: el hurto de hidrocarburos o sus derivados; el hurto de marcadores, detectores o reveladores; el contrabando de hidrocarburos y sus derivados; el favorecimiento en el delito de hurto de hidrocarburos o sus derivados, y el favorecimiento en el delito de contrabando de hidrocarburos o sus derivados. Empero, esta normatividad tuvo poca vigencia, pues la Corte Constitucional, en Sentencia C-939/02 del 31 de octubre de 2002, con ponencia de EduARDo MonteAlEgRE LynetT, la declaró inconstitucional, pues "si bien las principales modalidades delictuales consagradas en el decreto legislativo tenían conexidad con los motivos que dieron origen a la declaratoria de la conmoción interior, resultaban inexequibles por quebrantar los límites especiales que la Constitución le impone al Presidente en la conmoción interior" (Gaceta del Congreso 183 de 2005).

La expedición de la Ley 788 de 2002 para regular aspectos tributarios fue aprovechada, entonces, para introducir reformas al Código Penal (Ley 599 de 2000), que había iniciado su vigencia en julio 25 del año 2001, especialmente para incluir en este Estatuto de Penas las normas declaradas inexequibles por la Corte Constitu- 
cional. Así, se reformaron algunos tipos penales relacionados con el contrabando tradicional y se incorporaron al Capítulo IV, del Título x, los punibles relacionados con los hidrocarburos. Igualmente, vieron la luz los Artículos 319-1; 320-1; 322-1, que en su orden sancionan el contrabando de hidrocarburos y sus derivados; favorecimiento de contrabando de hidrocarburos o sus derivados y favorecimiento por servidor público de contrabando de hidrocarburos o sus derivados (HERNÁNDEZ QUINTERO, 2014, p. 83-84).

\section{H. EL FUTURO DEL DELITO DE CONTRABANDO EN COLOMBIA}

\section{Proyecto de Ley 094 de 2013}

El gobierno nacional, por conducto de los ministerios de Comercio, Industria y Turismo, y de Hacienda y Crédito Público presentó al Congreso de la República el Proyecto de Ley 094 de 2013, "Por medio del cual se adoptan instrumentos para prevenir, controlar y sancionar el contrabando, el lavado de activos y la evasión fiscal", el cual analizaremos en el presente aparte. El mencionado proyecto de ley plantea un problema centrado en la forma como se afectan diferentes sectores de la economía nacional y seguridad nacional, en razón al traslado de las ganancias derivadas del contrabando y el lavado de activos a grupos armados al margen de la ley, que los usan es sus actividades criminales, con un claro impacto en el orden público.

El proyecto advierte también el daño que sufren el aparato industrial y el sector comercializador de Colombia, actividades que compiten con quienes realizan sus mismas actividades, evaden impuestos y por ello pueden ofrecer mejores precios de venta. Es importante para el gobierno nacional afirmar que se reciente también el sector público tanto nacional como territorial, por dejar de percibir los impuestos que sirven para el desarrollo del país y de la población en general. Por otra parte, señala el proyecto que las conductas que se pretende combatir tienen origen en diferentes causas, entre las que se encuentran: la presencia de intereses económicos de organizaciones delictivas, la falta de oportunidades de la población, las posibilidades de dinero fácil y la impunidad. Ante esta situación, se pretende adelantar una estrategia integral que atienda las diferentes causas que generan las conductas mencionadas, destacándose en primer lugar la regulación penal.

Afirma el Gobierno Nacional en el mencionado proyecto de ley que

Se prevé una adecuación de los tipos penales contemplados por la Ley 599 de 2000 relacionados con el contrabando, el favorecimiento del contrabando y el lavado de activos. Si bien el Código Penal prevé algunos tipos penales, no aborda la totalidad de las modalidades específicas en materia de delincuencia aduanera. Esto implica que muchas de las conductas que más perjuicios están generando a la industria nacional, no están típicamente previstas como delito. 
El Proyecto de Ley se vale de la descripción y análisis de las modalidades propuestas para poder reorientar el Código Penal de forma que permita la persecución efectiva de conductas. Si bien la modalidad de ejecución de las conductas es compleja, la redacción de los tipos penales debe ser simple y enfocarse en los aspectos determinantes de cada una de las modalidades de las conductas. De lo contrario, ante tipos penales demasiado complejos, se genera un riesgo de impunidad. Esto último se presenta debido a que cada elemento descrito en el tipo penal es un elemento que debe ser probado por el ente acusador.

Por lo anterior, el Proyecto de Ley propone la modernización de los tipos penales asociados al contrabando. Asimismo, se busca fortalecer las normas de receptación y de favorecimiento, en los eventos que tienen relación con el contrabando.

El primer capítulo del Proyecto de Ley hace reformas a la Ley 599, que podría pensarse que son la adecuación a la que se refiere el gobierno nacional. Así, en lo relativo al delito de contrabando el Artículo 4 pretende modificar el 319 del actual Código Penal de la siguiente forma:

Artículo 319. Contrabando. El que introduzca mercancías al territorio colombiano o las exporte desde él por lugares no habilitados, o las oculte, disimule o sustraiga de la intervención y control aduanero, o las descargue en zona primaria aduanera sin que se encuentren amparadas en documento de viaje alguno, en cuantía superior a cincuenta (50) salarios mínimos legales mensuales, incurrirá en prisión de ocho (8) a doce (12) años y multa del doscientos $(200 \%)$ al trescientos $(300 \%)$ por ciento del valor aduanero de los bienes introducidos de manera ilegal o de los bienes exportados.

Si la conducta descrita en el inciso anterior recae sobre mercancías cuyo valor supere los doscientos (200) salarios mínimos legales mensuales, se impondrá una pena de diez (10) a catorce (14) años de prisión y multa del doscientos $(200 \%)$ al trescientos (300\%) por ciento del valor aduanero de los bienes introducidos de manera ilegal o de los bienes exportados. El monto de la multa no podrá superar el máximo de la multa establecida en este código.

Parágrafo 1. Los vehículos automotores que transiten en departamentos que tienen zonas de fronteras de acuerdo con lo estipulado en el artículo 85 de la Ley 633 de 2000, en concordancia con el artículo 24 de la Ley 191 de 1995, no estarán sometidos a lo establecido en este artículo.

Parágrafo 2. La legalización de las mercancías no extingue la acción penal. 
Se observa que la modificación fundamental en esta norma es el aumento de pena. Así, se pasa de una consecuencia punitiva de 3 a 5 y de 8 a 12 años de prisión, cuando el valor de la mercancía importada o exportada ilícitamente no supere los 50 salarios mínimos legales vigentes. Cuando la cuantía supere los 200 S.M.L.v, la pena será de 10 a 14 años (en el actual Código es de 5 a 8 años de prisión). Asimismo, se cambia la expresión "importe mercancías al territorio colombiano", por el de "introduzca" (verbo rector). En cuanto a la multa, se cambia de 300 a 1.500 S.M.L.V. a $200 \%$ al $300 \%$ del valor aduanero de los bienes introducidos de manera ilegal o de los bienes exportados.

Es importante destacar que en el proyecto de ley se elimina el inciso tercero del texto vigente que establece que las penas previstas se aumentarán de la mitad a las tres cuartas (3/4) partes cuando se demuestre que el sujeto activo de la conducta es reincidente.

En cuanto al delito de favorecimiento de contrabando consagrado en el artículo 320 del Código Penal en vigencia, el proyecto propone que en el futuro se denomine "Favorecimiento y facilitación del contrabando". Se le incluyen los nuevos verbos rectores de "embarque, desembarque, oculte, comercialice". En la norma se cambia la expresión "mercancía introducida al territorio colombiano por lugares no habilitados" por la de "mercancías que hayan ingresado al país ilegalmente" y se cambia la medida del valor de estas mercancías, de Unidad de Valor Tributario (UVT), por el de salarios mínimos legales mensuales vigentes (S.M.L.V). Asimismo, se establece que cuando no supere los 50 S.M.L.v, la pena será de 3 a 6 años de prisión y multa del $200 \%$ al $300 \%$ del valor aduanero de la mercancía (actualmente de 1 a 5 años y multa de 4.100 a 1.020.000 UVT). Finalmente, se agrega un inciso para precisar que, cuando el valor de la mercancía introducida ilegalmente al país supere los 200 S.M.L.V., la pena será de prisión de seis (6) a diez (10) años y multa de doscientos al trescientos $(300 \%)$ por ciento del valor aduanero de la mercancía en Colombia.

Se incluye un nuevo inciso a la norma para sancionar por favorecimiento y facilitación del contrabando a la persona que destine o adecúe bien mueble o inmueble con el fin de poseer, tener, transportar, almacenar, ocultar, distribuir, comercializar o enajenar mercancías que hayan ingresado al país ilegalmente.

Llama la atención el hecho de que se elimine el inciso tercero del actual artículo 320 del Código Penal, que preceptúa que no incurre en el delito de favorecimiento de contrabando el consumidor final cuando los bienes en su poder están soportados con los documentos exigidos por el Estatuto Tributario.

En cuanto al Artículo 321, se cambia su actual denominación de "Defraudación a las rentas de aduana" por el de "Fraude aduanero" y se modifica sustancialmente la conducta del tipo penal que, en el futuro, no será el declarar tributos aduaneros por un valor inferior al que por ley le corresponde, sino el suministrar información fal- 
sa, manipularla u ocultarla cuando le sea requerida por la autoridad aduanera o esté obligado a entregarla por mandato legal, siempre que la finalidad sea la de evadir total o parcialmente las obligaciones tributarias o aduaneras. La pena por este punible se aumenta considerablemente, pues pasa de cinco (5) a ocho (8) años y multa de veinte (20) veces lo dejado de declarar a ocho (8) a doce (12) años de prisión y multa de mil (1.000) a cincuenta mil (50.000) S.M.L.V.

De otra parte, se elimina el parágrafo que señalaba que este artículo no se aplicaba cuando el menor valor de los tributos aduaneros declarados se encuentra en controversia sobre su valoración, error aritmético en la liquidación de tributos o clasificación arancelaria.

Asimismo, se adicionan a la norma dos nuevos incisos. El primero indica que la pena señalada en el inciso primero se aplicará a quien utilice o se valga de empresas extranjeras para realizar las conductas descritas en el tipo penal. El segundo, anuncia similar pena para "quien falsifique o haga uso de etiquetas, códigos, marcas, descripciones o números seriales falsos de la mercancía importada, y con ello se logre la apariencia de veracidad de una operación aduanera”.

Ahora bien, en cuanto a las modificaciones relativas al delito de lavado de activos, el artículo 8 del mencionado Proyecto de Ley propone una modificación del Artículo 323 del Código Penal, que tendría esta nueva redacción: en este punto concreto, la modificación sustancial del presente proyecto es incluir los delitos de contrabando; contrabando de hidrocarburos o sus derivados; fraude aduanero, y el favorecimiento del contrabando como delitos fuente del punible de lavado de activos.

\section{El contrabando en la Ley 1762 de 2015}

Surtido el correspondiente trámite ante el Congreso Nacional, se dictó la Ley 1762 de julio 6 de 2015 (Diario Oficial n. ${ }^{\circ}$ 49565), en la cual, con algunas ligeras modificaciones, se sigue el proyecto comentado en el apartado anterior. A continuación resaltamos los cambios más importantes:

Contrabando. Artículo 319 del Código Penal:

Se cambia el verbo rector "exportar", por el de "Extraer". Asimismo, se mantiene como contravención administrativa el contrabando de mercancías menor a 50 salarios mensuales legales mínimos vigentes (S.M.L.M.V.) y se aumenta la pena mínima a 4 años (antes 3 y en el proyecto, 4) y la máxima a 8 años (antes $5 \mathrm{y}$ el en proyecto, 12).

Cuando el valor de mercancía de contrabando supere los 200 S.M.L.M.V., la pena será de 9 a 12 años (antes 5 a 8 y en proyecto, 10 a 14). 
Contrabando de hidrocarburos y sus derivados. Artículo 319.1

En la ley se establecen nuevos parámetros para sancionar este delito. Así, se crean tres categorías: la primera, cuando el contrabando de hidrocarburos y sus derivados está entre 20 y 50 galones (antes superior a 20 y menor de 80); la segunda, cuando se superan los 50 galones y la tercera, cuando se sobrepasan los 80 galones. La pena a imponer, en su orden, es de: 3 a 5 años de prisión (es igual a la pena actual); 4 a 8 años de prisión (antes no existía esta categoría) y 10 a 14 años de prisión (antes de 5 a 8 años).

Favorecimiento y facilitación del contrabando. Artículo 320

Al título del artículo se le agrega el término "facilitación". Asimismo, se cambia la medida de UVT, por salarios mensuales legales mínimos vigentes.

De otra parte, se incluyen otros verbos rectores: "embarcar", "desembarcar" y "ocultar".

Se establece que, cuando las mercancías objeto del contrabando que se favorece o facilita, supere los 50 s.M.L.M.V., sin superar los 200, la pena será de 3 a 6 años de prisión (antes 1 a 5 y en el proyecto de 3 a 6 ). En el evento que supere los 200 S.M.L.M.V, la consecuencia punitiva será de 6 a 10 años de prisión (esta categoría no existía en la ley anterior ni se propuso en el proyecto inicial).

En igual forma, se elimina el parágrafo propuesto en el proyecto, según el cual se sancionaba a "quien destine o adecúe bien mueble o inmueble, con el fin de poseer, tener, transportar, almacenar, ocultar, distribuir, comercializar o enajenar mercancías que hayan ingresado al país ilegalmente".

Favorecimiento de contrabando de hidrocarburos o sus derivados. Art. 320-1.

Se agrega al tipo penal los verbos rectores embarcar, desembarcar y ocultar. Asimismo, se disminuye la pena cuando los hidrocarburos o sus derivados cuyo contrabando se favorece, es superior a 20 galones e inferior a cincuenta. Este comportamiento se sanciona con prisión de 3 a 5 años (en la actualidad de 3 a 6 años).

De otra parte, se crean tres nuevas categorías: cuando el contrabando de hidrocarburos que se favorece supera los cincuenta galones; cuando la cantidad está por encima de los ochenta galones y cuando esta superan los mil galones. En su orden, la pena es de 4 a 8 años de prisión; 10 a 14 años de prisión y 12 a 16 años de prisión. 
Fraude aduanero. Art. 321

Se cambia el nombre de defraudación a las rentas de aduana por el de Fraude aduanero, como lo señalaba el proyecto de ley. Se mantiene la redacción básica propuesta en el proyecto, incluyendo la pena sugerida de 8 a 12 años de prisión (antes de 5 a 8 años).

Empero, se eliminan los parágrafos que sancionaban el comportamiento de fraude aduanero cuando el autor se valía de empresas extranjeras para realizar la conducta, al igual que el comportamiento de usar etiquetas, códigos, marcas, descripciones o números seriales falsos de la mercancía importada y con ella se lograra la apariencia de veracidad de una operación aduanera.

Por otra parte, se incluye, de nuevo, el parágrafo que traía originalmente el artículo 321 de la Ley 599 de 2000 y que se eliminaba en el proyecto, según el cual el fraude aduanero no se aplicará cuando se trate de un error aritmético, sin perjuicio de la aplicación de las sanciones administrativas correspondientes.

Favorecimiento por servidor público. Art. 322

En la nueva redacción de la norma se incluye los nuevos verbos rectores de embarcar, desembarcar y almacenar.

Asimismo, se cambia la pena de multa por la de prisión. Así, cuando la mercancía vinculada al ilícito supere los cincuenta salarios mínimos legales la consecuencia punitiva será de cuatro a ocho años de prisión y multa de 1.000 a 50.000 S.M.L.M.V (antes multa de 300 a 1.500 S.M.L.MV.). Cuando la mercancía involucrada en la conducta delictual esté por encima de los cincuenta salarios mensuales legales mensuales vigentes, la pena será de nueve a doce años de prisión (antes 5 a 8 años), la inhabilitación de derechos y funciones públicas por el mismo tiempo de la pena principal y multa de mil a cincuenta mil S.M.L.M.V. (antes 1.500 a 50.000 S.M.L.M.V.)

De otra parte, se crea una nueva categoría para cuando el favorecimiento se realiza sobre mercancía cuyo valor real supere los doscientos salarios mínimos legales mensuales vigentes, evento en el cual se impondrá una pena de prisión entre once a quince años, inhabilitación de derechos y funciones públicas por el mismo tiempo de la pena principal y multa de mil a cincuenta mil S.M.L.M.V.

Favorecimiento por servidor público de contrabando de hidrocarburos o sus Derivados. Art. 322-1

En este comportamiento delictual se incluyen tres nuevos verbos rectores: embarcar, desembarcar y almacenar. 
Asimismo, se cambia la pena de multa por la de prisión de cinco a nueve años, cuando el favorecimiento del servidor público se realiza sobre hidrocarburos o sus derivados, cuya cuantía sea inferior a los cincuenta galones (antes 20 galones). La inhabilitación de derechos y funciones públicas será por el mismo tiempo de la pena principal (antes de 3 a 5 años). Cuando la conducta recae sobre hidrocarburos o sus derivados que superen los cincuenta galones la pena a imponer será de diez a catorce años e inhabilitación de derechos y funciones públicas por el mismo tiempo de la pena principal y multa de mil a cincuenta mil S.M.L.M.V. (antes multa de cincuenta S.M.L.M.V. cuando superaba los veinte galones).

De otra parte, se crea una nueva categoría cuando la conducta recae sobre una cantidad de hidrocarburos o sus derivados que supera los quinientos galones, evento en el cual la pena será de doce a dieciséis años de prisión, inhabilitación de derechos y funciones públicas por el mismo tiempo y multa de mil a cincuenta mil S.M.L.M.V.

Lavado de activos. Art. 323

Se incluye como delitos base del lavado de activos los ilícitos de contrabando; contrabando de hidrocarburos o sus derivados; fraude aduanero y favorecimiento y facilitación del contrabando en cualquiera de sus formas, siguiendo de cerca lo propuesto en el proyecto de ley.

De otra parte, se aumenta la pena de multa de mil a cincuenta mil salarios mínimos legales mensuales vigentes (antes 650 a 50.000 S.M.L.M.V.).

De esta forma, la redacción de las nuevas disposiciones en relación con el delito de contrabando en Colombia son del siguiente tenor:

Artículo 319. Contrabando. El que introduzca o extraiga mercancías en cuantía superior a cincuenta (50) salarios mínimos legales mensuales, al o desde el territorio colombiano por lugares no habilitados de acuerdo con la normativa aduanera vigente, incurrirá en prisión de cuatro (4) a ocho (8) años y multa del doscientos $(200 \%)$ al trescientos $(300 \%)$ por ciento del valor aduanero de los bienes objeto del delito.

En (sic) que oculte, disimule o sustraiga de la intervención y control aduanero mercancías en cuantía superior a cincuenta (50) salarios mínimos legales mensuales, o las ingrese a zona primaria definida en la normativa aduanera vigente sin el cumplimiento de las formalidades exigidas en la regulación aduanera, incurrirá en la misma pena de prisión y multa descrita en el inciso anterior. 
Si las conductas descritas en los incisos anteriores recaen sobre mercancías en cuantía superior a doscientos (200) salarios mínimos legales mensuales, se impondrá una pena de nueve (9) a doce (12) años de prisión y multa del doscientos $(200 \%)$ al trescientos $(300 \%)$ por ciento del valor aduanero de los bienes objeto del delito.

Se tomará como circunstancias de agravación punitiva, que el sujeto activo tenga la calidad de Usuario Altamente Exportador (Altex), de un Usuario Aduanero Permanente (UAP), o de un Usuario u Operador de Confianza, de un Operador Económico Autorizado (OEA) o de cualquier operador con un régimen especial de acuerdo con la normativa aduanera vigente. Asimismo será causal de mayor punibilidad la reincidencia del sujeto activo de la conducta.

Parágrafo. La legalización de las mercancías no extingue la acción penal.

Artículo 319-1. Contrabando de hidrocarburos y sus derivados. El que en cantidad superior a veinte (20) galones e inferior a cincuenta (50) introduzca hidrocarburos o sus derivados al territorio colombiano, o los extraiga desde él, por lugares no habilitados de acuerdo con la normativa aduanera vigente, incurrirá en prisión de tres (3) a cinco (5) años y multa de ciento cincuenta (150) a setecientos cincuenta (750) salarios mínimos mensuales legales vigentes.

El que descargue en lugar de arribo hidrocarburos o sus derivados en cantidad superior a veinte (20) galones e inferior a cincuenta (50), sin el cumplimiento de las formalidades exigidas en la regulación aduanera, incurrirá en la misma pena de prisión y multa descrita en el inciso anterior.

El que oculte, disimule o sustraiga de la intervención y control aduanero hidrocarburos o sus derivados en cantidad superior a veinte (20) galones e inferior a cincuenta (50), incurrirá en la misma pena de prisión y multa descrita en el inciso $1^{\circ}$ de este artículo.

Si las conductas descritas en el (sic) incisos anteriores recaen sobre hidrocarburos o sus derivados cuya cantidad supere los cincuenta (50) galones, se impondrá una pena de cuatro (4) a ocho (8) años y multa de trescientos (300) a mil quinientos (1.500) salarios mínimos mensuales legales vigentes, sin que en ningún caso sea inferior al doscientos por ciento (200\%) del valor aduanero de los hidrocarburos o sus derivados objeto del delito.

Si las conductas descritas en los incisos anteriores recaen sobre hidrocarburos o sus derivados cuya cantidad supere los ochenta (80) galones, se impondrá una pena de diez (10) a catorce (14) años de prisión y multa de mil quinientos (1.500) a cincuenta mil (50.000) salarios mínimos legales mensuales vigentes, sin que en ningún caso sea inferior al doscientos por ciento (200\%) del valor 
aduanero de los hidrocarburos o sus derivados objeto del delito. El monto de la multa no podrá superar el máximo de la pena de multa establecido en este código.

Si las conductas descritas en los incisos anteriores recaen sobre hidrocarburos o sus derivados cuya cantidad supere los mil (1.000) galones, se impondrá una pena de doce (12) a dieciséis (16) años de prisión y multa de mil quinientos (1.500) a cincuenta mil (50.000) salarios mínimos legales mensuales vigentes, sin que en ningún caso sea inferior al doscientos por ciento $(200 \%)$ del valor aduanero de los hidrocarburos o sus derivados objeto del delito. El monto de la multa no podrá superar el máximo de la pena de multa establecido en este Código.

Parágrafo. La legalización de las mercancías no extingue la acción penal.

Artículo 320. Favorecimiento y facilitación del contrabando. El que posea, tenga, transporte, embarque, desembarque, almacene, oculte, distribuya, enajene mercancías que hayan sido introducidas al país ilegalmente, o que se hayan ocultado, disimulado o sustraído de la intervención y control aduanero o que se hayan ingresado a zona primaria sin el cumplimiento de las formalidades exigidas en la regulación aduanera, cuyo valor supere los cincuenta (50) salarios mínimos legales mensuales vigentes, sin superar los doscientos (200) salarios mínimos legales mensuales vigentes, incurrirá en pena de prisión de tres (3) a seis (6) años y multa del doscientos por ciento (200\%) al trescientos por ciento (300 \%) del valor aduanero de la mercancía objeto del delito.

Si la conducta descrita en el inciso anterior recae sobre mercancías cuyo valor supere los doscientos (200) salarios mínimos legales mensuales vigentes, incurrirá en pena de prisión de seis (6) a diez (10) años, y multa del doscientos por ciento (200\%) al trescientos por ciento (300\%) del valor aduanero de la mercancía objeto del delito.

No se aplicará lo dispuesto en el presente artículo al consumidor final cuando los bienes que se encuentren en su poder, estén soportados con factura o documento equivalente, con el lleno de los requisitos legales contemplados en el artículo 771-2 del Estatuto Tributario.

Artículo 320-1. Favorecimiento de contrabando de hidrocarburos o sus derivados. El que posea, tenga, transporte, embarque, desembarque, almacene, oculte, distribuya, enajene hidrocarburos o sus derivados que hayan ingresado al país ilegalmente, o que se hayan descargado en lugar de arribo sin cumplimiento de la normativa aduanera vigente, o que se hayan ocultado, disimulado o sustraído de la intervención y control aduanero cuya cantidad sea superior a veinte (20) galones e inferior a cincuenta (50), se impondrá una 
pena de prisión de tres (3) a cinco (5) años y multa de ciento cincuenta (150) a setecientos cincuenta (750) salarios mínimos mensuales legales vigentes, sin que en ningún caso sea inferior al doscientos por ciento (200\%) del valor aduanero de los hidrocarburos o sus derivados objeto del delito.

Si la conducta descrita en el inciso anterior recae sobre hidrocarburos o sus derivados cuya cantidad supere los cincuenta (50) galones, incurrirá en pena de prisión de cuatro (4) a ocho (8) años y multa de trescientos (300) a mil quinientos (1.500) salarios mínimos legales mensuales vigentes, sin que en ningún caso sea inferior al doscientos por ciento (200\%) del valor aduanero de los hidrocarburos o sus derivados objeto del delito.

Si la conducta descrita en el inciso $1^{\circ}$ recae sobre hidrocarburos o sus derivados cuya cantidad supere los ochenta (80) galones, incurrirá en pena de prisión de diez (10) a catorce (14) años, y multa de trescientos (300) a mil quinientos (1.500) salarios mínimos legales mensuales vigentes, sin que en ningún caso sea inferior al doscientos por ciento (200\%) del valor aduanero de las mercancías.

Si la conducta descrita en el inciso primero, recae sobre hidrocarburos o sus derivados cuya cantidad supere los mil (1.000) galones, incurrirá en pena de doce (12) a dieciséis (16) años, y multa de trescientos (300) a mil quinientos (1.500) salarios mínimos legales mensuales vigentes, sin que en ningún caso sea inferior al doscientos por ciento (200\%) del valor aduanero de las mercancías.

No se aplicará lo dispuesto en el presente artículo al consumidor final cuando los bienes que se encuentren en su poder, estén soportados con factura o documento equivalente, con el lleno de los requisitos legales contemplados en el artículo 771-2 del Estatuto Tributario.

Artículo 321. Fraude Aduanero. El que por cualquier medio suministre información falsa, la manipule u oculte cuando le sea requerida por la autoridad aduanera o cuando esté obligado a entregarla por mandato legal, con la finalidad de evadir total o parcialmente el pago de tributos, derechos o gravámenes aduaneros a los que esté obligado en Colombia, en cuantía superior a veinte (20) salarios mínimos legales mensuales vigentes del valor real de la mercancía incurrirá en pena de prisión de ocho (8) a doce (12) años, y multa de mil (1.000) a cincuenta mil (50.000) salarios mínimos legales mensuales vigentes.

Parágrafo. Lo dispuesto en el presente artículo no se aplicará cuando el valor distinto de los tributos aduaneros declarados corresponda a error aritmético en la liquidación de tributos, sin perjuicio de la aplicación de las sanciones administrativas establecidas en la ley. 
Artículo 322. Favorecimiento por servidor público. El servidor público que colabore, participe, embarque, desembarque, transporte, distribuya, almacene, oculte, enajene o de cualquier forma facilite la sustracción, ocultamiento o disimulo de mercancías del control de las autoridades aduaneras, o la introducción de las mismas por lugares no habilitados, u omita los controles legales o reglamentarios propios de su cargo para lograr los mismos fines, cuando el valor real de la mercancía involucrada sea inferior a cincuenta (50) salarios mínimos legales mensuales vigentes, incurrirá en prisión de cuatro (4) a ocho (8) años, inhabilitación de derechos y funciones públicas por el mismo tiempo de la pena de prisión impuesta, y multa de mil (1.000) a cincuenta mil (50.000) salarios mínimos mensuales vigentes, sin que en ningún caso sea inferior al doscientos por ciento $(200 \%)$ del valor aduanero del objeto de la conducta.

Si la conducta descrita en el inciso anterior recae sobre mercancías cuyo valor real supere los cincuenta (50) salarios mínimos legales mensuales vigentes, se impondrá una pena de prisión de nueve (9) a trece (13) años, inhabilitación de derechos y funciones públicas por el mismo tiempo de la pena de prisión impuesta, y multa de mil (1.000) a cincuenta mil (50.000) salarios mínimos mensuales vigentes, sin que en ningún caso sea inferior al doscientos por ciento $(200 \%)$ del valor aduanero del objeto de la conducta.

Si la conducta descrita en el inciso anterior recae sobre mercancías cuyo valor real supere los doscientos (200) salarios mínimos legales mensuales vigentes, se impondrá una pena de prisión de once (11) a quince (15) años, inhabilitación de derechos y funciones públicas por el mismo tiempo de la pena de prisión impuesta, y multa de mil (1.000) a cincuenta mil (50.000) salarios mínimos mensuales vigentes, sin que en ningún caso sea inferior al doscientos por ciento (200\%) del valor aduanero del objeto de la conducta.

El monto de la multa no podrá superar el máximo de la pena de multa establecida en este Código.

Artículo 322-1. Favorecimiento por servidor público de contrabando de hidrocarburos o sus derivados. El servidor público que colabore, participe, embarque, desembarque, transporte, distribuya, almacene, oculte, enajene o de cualquier forma facilite la sustracción, ocultamiento o disimulo de hidrocarburos o sus derivados del control de las autoridades aduaneras, o la introducción de las mismas por lugares no habilitados, u omita los controles legales o reglamentarios propios de su cargo para lograr los mismos fines, cuando la cantidad de los hidrocarburos o sus derivados sea inferior a los cincuenta (50) galones, incurrirá en prisión de cinco (5) a nueve (9) años, inhabilitación derechos y funciones públicas por el mismos tiempo de la pena de prisión impuesta, y multa de mil (1.000) a cincuenta mil (50.000) salarios 
mínimos mensuales vigentes, sin que en ningún caso sea inferior al doscientos por ciento $(200 \%)$ del valor aduanero del objeto de la conducta.

Si la conducta descrita en el inciso anterior recae sobre una cantidad de hidrocarburos o sus derivados que supere los cincuenta (50) galones, se impondrá una pena de prisión de diez (10) a catorce (14) años, inhabilitación derechos y funciones públicas por el mismo tiempo de la pena de prisión impuesta, y multa de mil (1.000) a cincuenta mil (50.000) salarios mínimos mensuales vigentes, sin que en ningún caso sea inferior al doscientos por ciento $(200 \%)$ del valor aduanero del objeto de la conducta.

Si la conducta descrita en el primer inciso, recae sobre una cantidad de hidrocarburos o sus derivados que supere los quinientos (500) galones, se impondrá una pena de prisión de doce (12) a dieciséis (16) años, inhabilitación derechos y funciones públicas por el mismo tiempo de la pena de prisión impuesta, y multa de mil (1.000) a cincuenta mil (50.000) salarios mínimos mensuales vigentes, sin que en ningún caso sea inferior al doscientos por ciento $(200 \%)$ del valor aduanero del objeto de la conducta.

El monto de la multa no podrá superar el máximo de multa establecida en este Código.

Artículo 323. Lavado de activos. El que adquiera, resguarde, invierta, transporte, transforme, almacene, conserve, custodie o administre bienes que tengan su origen mediato o inmediato en actividades de tráfico de migrantes, trata de personas, extorsión, enriquecimiento ilícito, secuestro extorsivo, rebelión, tráfico de armas, tráfico de menores de edad, financiación del terrorismo y administración de recursos relacionados con actividades terroristas, tráfico de drogas tóxicas, estupefacientes o sustancias sicotrópicas, delitos contra el sistema financiero, delitos contra la administración pública, contrabando, contrabando de hidrocarburos o sus derivados, fraude aduanero o favorecimiento y facilitación del contrabando, favorecimiento de contrabando de hidrocarburos o sus derivados, en cualquiera de sus formas, o vinculados con el producto de delitos ejecutados bajo concierto para delinquir, o les dé a los bienes provenientes de dichas actividades apariencia de legalidad o los legalice, oculte o encubra la verdadera naturaleza, origen, ubicación, destino, movimiento o derecho sobre tales bienes o realice cualquier otro acto para ocultar o encubrir su origen ilícito, incurrirá por esa sola conducta, en prisión de diez (10) a treinta (30) años y multa de mil (1.000) a cincuenta mil (50.000) salarios mínimos legales mensuales vigentes.

La misma pena se aplicará cuando las conductas descritas en el inciso anterior se realicen sobre bienes cuya extinción de dominio haya sido declarada. 
El lavado de activos será punible aun cuando las actividades de que provinieren los bienes, o los actos penados en los apartados anteriores, se hubiesen realizado, total o parcialmente, en el extranjero.

Las penas privativas de la libertad previstas en el presente artículo se aumentarán de una tercera parte a la mitad cuando para la realización de las conductas se efectuaren operaciones de cambio o de comercio exterior, o se introdujeren mercancías al territorio nacional.

\section{REFERENCIAS}

Aldana Rozo, Luís Enrique (1977). "El Estatuto Penal Aduanero", en Revista Derecho Penal y Criminología, año 1, número 1. Bogotá: Universidad Externado de Colombia.

CAdAvid Orozco, IvÁN (s.f.). El delito de contrabando. Medellín: Impresos SúPer.

CusgüEn Olarte, EduARdo (2005). Evasión y Contrabando. Bogotá: Leyer editorial.

BazZani Montoya, Darío (2001). "El delito de contrabando", en Memorias XXIII Jornadas Internacionales de Derecho Penal. Bogotá: Universidad Externado de Colombia.

Hernández Quintero, Hernando A. (editor académico) (2014). “Del contrabando al delito de destinación ilegal de combustibles", en Apoderamiento de hidrocarburos - Aspectos Penales. Ibagué: Universidad de Ibagué.

Hernández Quintero, Hernando A. (2002). El lavado de activos. Tercera edición. Bogotá: Ediciones Jurídicas Gustavo Ibáñez.

IbÁÑEz GuZmán, Augusto J.; Ospina López, Guillermo J .; NeVito Gómez, Nelson (2004). El delito fiscal. Bogotá: Ediciones Jurídicas Gustavo Ibáñez.

Laurent, Muriel (2008). Contrabando en Colombia en el siglo XIX .Prácticas y discursos de resistencia y reproducción. Bogotá: Universidad de los Andes.

LAurent, Muriel (2009). "Y todos ellos roban a sus conciudadanos. Acerca del delito de contrabando en el siglo XIX colombiano", en Revista Historia Crítica Edición Especial. Bogotá: Universidad de los Andes.

Medina López, Roberto (1991). Despenalización del contrabando. Bogotá: Ediciones Librería del Profesional. 
Montealegre Lynett, Eduardo (1985). "Los terceros de buena fe en el Derecho Penal Aduanero", en Revista Derecho Penal y Criminología. Vol. viII, n. 25. Bogotá: Universidad Externado de Colombia. 